\title{
The transition of brazilian workers to formality: evidences from duration analysis
}

\section{La transición de los trabajadores brasileños a la formalidad: un análisis de duración}

\author{
Michele Romanello * \\ Flávio de Oliveira-Gonçalves **
}

\begin{abstract}
This paper aims to evidence the characteristics of individuals that affect more the transition from informal to formal sector in Brazil. The initial hypothesis is that the level of education of an individual is the most important characteristic. We utilize parametric and non-parametric survival analysis. Through the hazard function was possible to investigate what factors affect the risk of transiting to formality for a worker. For this analysis, we use the data from the Monthly Employment Survey (PME). The level of education appears to be the main characteristic that explains the exit of workers from informality.
\end{abstract}

Keywords: survival analysis, informality, education, Brazil.

\section{Resumen}

Este estudio tiene como objetivo mostrar las características de los individuos que más afectan la transición del sector informal al sector formal en Brasil. La hipótesis de partida es que el nivel de la educación es la característica más importante. Utilizamos el análisis paramétrico y no paramétrico de supervivencia: con función de riesgo, fue posible investigar los factores que afectan el riesgo de la transición a la formalidad. Para este análisis se utilizaron los datos de la Encuesta Mensual de Empleo (PME). El nivel de educación parece ser la característica principal que explica la salida de la informalidad.

Palabras clave: análisis de supervivencia, informalidad, educación, Brasil.

\footnotetext{
* Universidade Federal de Santa Catarina (UFSC), Brasil, correo-e: romanello.michele@gmail.

** Universidade Federal do Paraná (UFPR), Brasil, correo-e: flaviogonsalves@hotmail.com
} com 


\section{Introduction}

The decrease of informal market in the last decade can be considered one of the main changes in Brazilian economy. After decades (1980s-1990s) in which informal labor grew consistently, reaching a very high level, the last decade it witnessed the reverse process. The figures (National Household Survey - PNAD) evidence the change very clearly: the proportion of employed people in the informal sector decreased from $55.1 \%$ in 2001 to $48.7 \%$ in 2009 , with a fall of 6.4 percentage points.

Researches on this change are necessary for providing to decision makers with public policies evidences of the ways to reduce further informality. In fact, high levels of informality make difficult to access goods and services restricted to formal workers, promote unequal competition in the product market, and generate adverse macroeconomic impacts on pension and tax collection.

This paper aims to evidence the characteristics of individuals that affect more the transition from informal to formal sector. The initial hypotheses are that the characteristics linked to the level of education of an individual are the most important in explaining this transition. To achieve this purpose, we utilize parametric and non-parametric survival analysis. Through the hazard function it is possible to investigate what factors affect the risk of occurrence of the event, i.e., individuals leave the state of informality to reach formality. For this, we use the data from the Monthly Employment Survey (PME) from January 2004 to December 2013. PME surveys the Metropolitan Regions of Rio de Janeiro, São Paulo, Porto Alegre, Belo Horizonte, Recife, and Salvador; which are the six biggest metropolitan areas of Brazil in terms of population according to Brazilian Census in 2000. Two metropolitan regions of this survey, Recife and Salvador, are situated in the North-East of Brazil; three, Rio de Janeiro, São Paulo and Belo Horizonte, in the Southeast macroregion; and one, Porto Alegre, in the South of the country. In this paper, formality and informality are considered only at the level of workers, not contemplating entrepreneurs, that is, formal workers are employees with formal contract (signed work booklet) and informal workers are employees without formal contract. A traditional classification in the Brazilian literature classifies as informal workers those who do not have a signed work booklet. To have signed a work booklet means to be registered as an employee and to have the certainty of certain right, including category minimum wage, paid vacation, guarantee fund, weekly rest, guaranteed income for the worker and his family in times of incapacity to work caused by illness, accident, and pregnancy. 
The essay is divided into four sections, excluding introduction and conclusions: in the first section, data of recent decrease of Brazilian informality are presented; in the second section, other researches about the topic are evidenced through a literature review; in the third section, parametric and non-parametric models of duration are explained from a theoretical point of view, along with the database; in the fourth section, the results of duration analysis are showed and commented.

\section{Evidences of recent decrease in Brazilian informality}

Brazilian Federal Constitution of 1988 allowed considerable progress in formalization of society in the 1980s; examples of this are the incorporation of the rural social security system and the creation of a universal Social Security. However, this process of formalization of society was interrupted in the successive decade. In fact, in the 1990s, the confluence of technological, productive, and financial changes worldwide, in addition to deregulation and weakening of institutions that structured working relationships, pressured the labour market towards a relative reduction of formalization. Beyond this, we can add the deep economic crisis due to hyperinflation that struck Brazil in that decade. It was only in the 2000's that this trend in the labour market was reversed in a context of economic growth, social policy redesign, and restructure the state's ability to develop public policy in society (IPEA, 2011).

As we can see in figure 1, the proportion of workers employed informally changed from $57.39 \%$ in 2002 to $44.38 \%$ in 2012 , with a fall of 13.01 percentage points in ten years. The drop is more relevant if we compare it with the previous period (1992-2001) where this ratio was constant or increased depending on the year in question.

Considering a demographic analysis of this change, we can analyse the data relative to sex. Data from figure 2 show that, in relative terms, the increase of formalization was higher among women in the last years. Informal jobs among men passed from $56.45 \%$ in 2002 to $43.85 \%$ in 2012 (decrease of 12.60 percentage points), against a change from $58.73 \%$ to $45.09 \%$ among women (decrease of 13.64 percentage points). We can also observe that from 1992 to 2012 the gap of informality between men and women is narrowing: in the period 1992-1995 the gap was around 6-7 percentage points, while in the period 1996-2009 it was stable at 2-3 percentage points and, finally, in 2011-2012 dropped to one percentage point. 
Figure 1

\section{Proportion of informal workers (\%)}

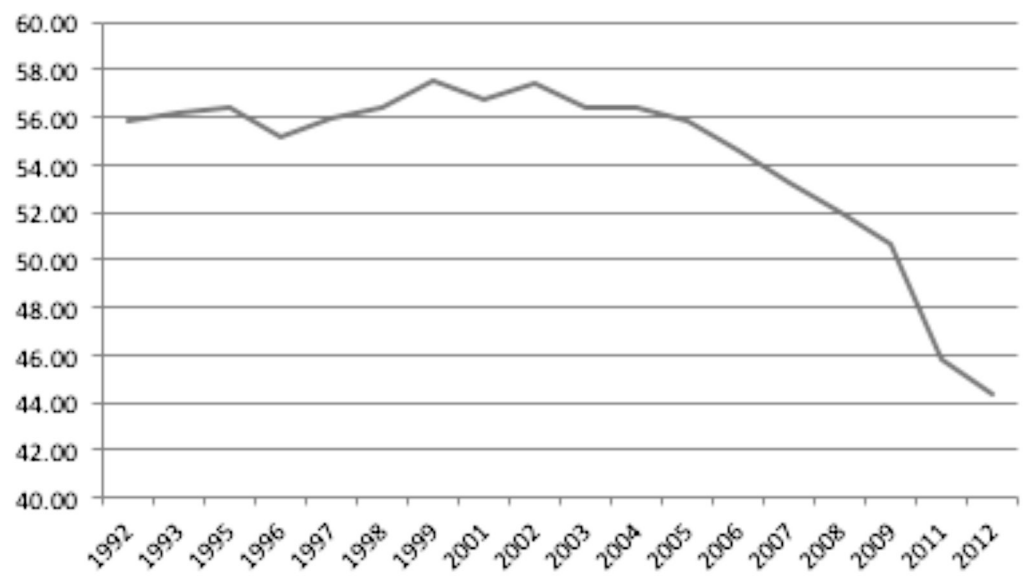

Source: own elaboration, pesquisa nacional por amostra de domicílios (IBGE, 1992-2012).

Figure 2

Proportion of informal workers by sex (\%)

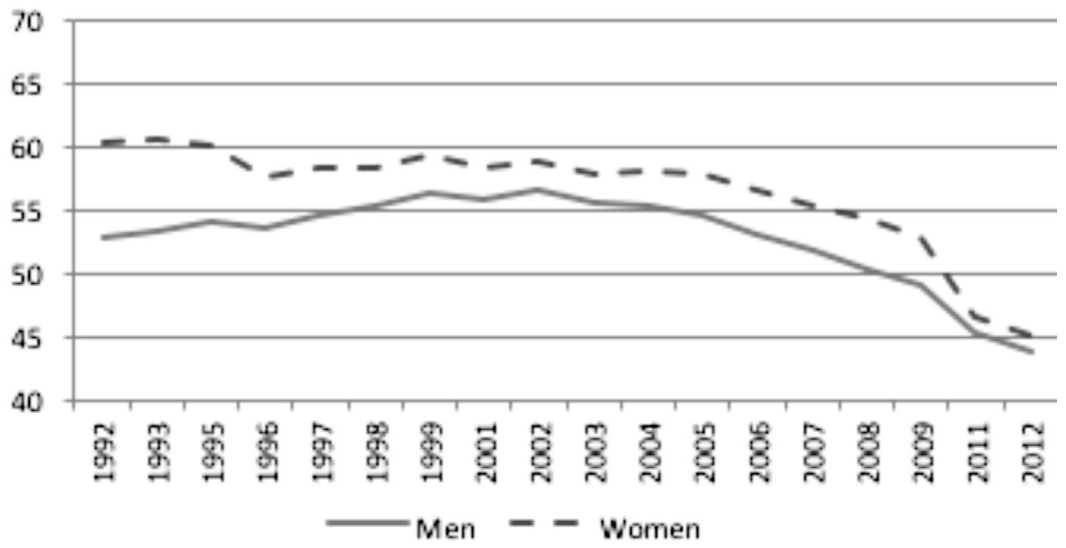

Source: own elaboration, pesquisa nacional por amostra de domicílios (IBGE, 1992-2012).

Regarding ethnicity (figure 3), the greatest advances in formalization occurred among those whose proportion of informal workers came from a higher level, namely blacks, browns, and Amerindians. For these ethnicities, the percentage of informal workers decreased between 2002 and 2012 from 64.68 to 50.27 , totalizing a difference of 14.41 percentage points. The fall in informality is less pronounced when we consider white and yellow workers in the same period: they passed from $50.28 \%$ in 2002 to $36.96 \%$ in 2012 , reducing informality by 13.32 percentage points. We 
have to point out that in this case the fall of informality among the categories is less pronounced than in the case of sex.

Figure 3

Proportion of informal workers by ethnicity (\%)

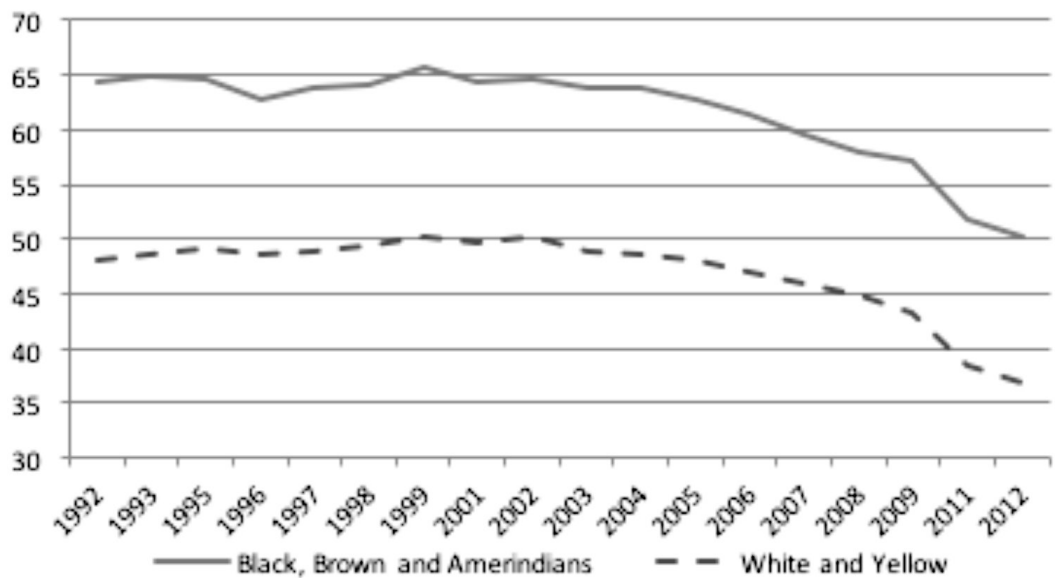

Source: own elaboration, pesquisa nacional por amostra de domicílios (IBGE, 1992-2012).

Regarding the years of study, the data in table 1 show that formalization was increasing with schooling among workers.

Table 1

Proportion of informal workers by level study completed (\%)

\begin{tabular}{lrrrrr}
\hline & Illiterate & \multicolumn{1}{c}{ Element } & Primary & \multicolumn{1}{c}{ Second } & Higher \\
\hline 1992 & 84.17 & 58.62 & 40.69 & 24.50 & 12.88 \\
1993 & 85.59 & 59.25 & 42.77 & 25.47 & 13.81 \\
1995 & 84.88 & 60.65 & 44.18 & 27.52 & 14.75 \\
1996 & 83.84 & 60.11 & 44.20 & 29.29 & 16.84 \\
1997 & 84.48 & 61.59 & 45.29 & 29.48 & 18.27 \\
1998 & 85.05 & 62.55 & 47.09 & 31.55 & 19.43 \\
1999 & 86.52 & 64.35 & 49.77 & 32.58 & 19.12 \\
2001 & 85.28 & 65.24 & 51.04 & 34.43 & 21.39 \\
2002 & 85.46 & 66.81 & 53.99 & 36.14 & 22.15 \\
2003 & 85.52 & 66.58 & 55.06 & 35.20 & 21.45 \\
2004 & 85.94 & 67.73 & 55.32 & 35.22 & 21.18 \\
2005 & 85.65 & 67.60 & 55.09 & 35.45 & 21.62 \\
2006 & 85.49 & 67.00 & 55.29 & 35.37 & 21.64 \\
2007 & 84.96 & 65.99 & 55.05 & 34.89 & 21.36 \\
2008 & 84.51 & 64.93 & 54.88 & 34.55 & 22.49 \\
2009 & 84.19 & 64.82 & 54.12 & 34.17 & 21.09 \\
2011 & 83.05 & 61.18 & 48.90 & 30.65 & 19.16 \\
2012 & 82.34 & 59.75 & 48.33 & 30.16 & 19.62 \\
\hline
\end{tabular}

Source: own elaboration, Pesquisa nacional por amostra de domicílios (IBGE, 1992-2012). 
In each year, informality is decreasing according to the level of education reached by the worker. The difference between the first category, illiterate, and the last one, higher education, is very significant: the average difference in all years is around 65 percentage points. The probable effect of education on recent reduction of informality can be observed only in the period 2006-2012. In fact, in that period, we can see a reduction of informality by around 7 percentage points among workers with elementary and primary education, by around 5 percentage points among workers with secondary education and by 2 percentage points among workers with higher education.

It is also interesting to evidence that informality increased in the higher levels of study. This fact can be explained by the presence of elements of heterogeneity in these levels of schooling. For instance, ValdiviaLópez and Pedrero-Nieto (2011) evidence that experience can play an important role in the dynamics of heterogeneity within the same level of education, affecting wage premium in their study, while informality in this paper.

\section{Literature review}

The International Labour Organization (ILO, 2014) affirms that the first step towards designing effective policies to enable transitions to formality is to identify the heterogeneity of the informal economy, the different categories of workers involved, and the drivers that are leading to the growth of the informal economy. Workers in the informal economy differ widely in terms of income, basic characteristics (sex, age), status in employment (employees, employers, own-account workers), sector (trade, agriculture, industry), type and size of enterprise, and location (urban or rural).

ILO (2014) tries to explain also the large presence of women in the informal sector. Part of the explanation lies in unequal burden of unpaid family duties that are given to women. In every society, the fact that women tend to spend more hours in unpaid work than men limits their choices about labour market participation, working hours and the place of their work. The informal economy may be the only way for women combining paid work with family responsibilities, given the sufficient flexibility and autonomy of this sector.

On the same topic, Cacciamali and José-Silva (2003) evidence that an important feature of the Brazilian labour market is the unequal distribution of unemployment and precarious occupations, leading to the fact that youth and women are among the most affected by these two situations. 
Gonzalez de la Rocha (1994) justifies the attractiveness of the informal sector for older workers arguing that they have incentives to migrate voluntarily for this sector, due to the fact that they are older and less educated. The lack of skills, the desire to leave the competitive and stressful position of employee, and even the opportunity to obtain higher income than in the formal sector, since their personal characteristics interfere negatively on wages, are factors that influence these individuals to be inserted as informal, mostly as entrepreneurs.

With regard to the education of informal workers, there is a large consensus in Brazilian literature (Barros, et al., 1993; Cacciamali and Fernandes, 1993; Neri, 2002) that they have, on average, fewer years of schooling than formal employees.

On the same topic, Carneiro and Henley (2001) explain that the return to education is lower among informal workers.

However, Curi and Menezes-Filho (2004) have a contrary opinion about what the literature affirms with regard to the qualifications of workers in informal sectors. When analysing the evolution of the Brazilian urban labour market during the 1990s, it was observed that there was an increase in informality in all levels of education, particularly among the highest.

In their work, Carneiro and Henley (2001) calculate also the probability of working in the formality: it is inferior for women, white, unionized, and urban workers. Moreover, they study the level of salaries and education in the formal and the informal sector. They conclude that the average wages between workers of the two markets are similar, though informal workers have less access to secondary and superior education.

Furthermore, considering the sectors of the economy, they affirm that construction and services are those that encourage informality, while administrative, industry, transport, and communications are those in which informal work is less present.

The literature about transition between formal and informal sector is also interesting. For Mexico, Maloney (1999), through transition matrices and a multinomial logit model show that the transition of workers from the formal to the informal sector is as likely as the transition in reverse. For Brazil, Barros et al. (1990) do a similar job for the Metropolitan Region of São Paulo, and show that 9\% of workers has transited between formality and informality in one year, and that about $50 \%$ of workers employed without a formal contract will be in the formal sector in the next year.

Neri (2002), in turn, with a transition matrix with data from the Monthly Employment Survey (PME) for the years between 1982 and 1997 , shows that the probability of exit from one job in the informal 
sector and going to one in the formal sector is almost the same that for the formal sector.

\section{Empirical methodology and database}

\subsection{Parametric models of duration}

Econometric models of duration are models regarding the length of time spent in a given state before transition to another state.

The duration models (also called models of survival analysis) can be utilized in several studies in economics, most of them refer to the time of transition from the state of unemployment to employment.

Generally, the duration models are commonly used in two types of analysis: (i) estimating the probability of the event to continue as it has lasted until a determined time or (ii) estimating the probability that the event ends in the next period, given that it lasted until the current period (Lancaster, 1979). For analysing the transition from informality to formality and the factors that affect this change, this paper utilizes the second approach.

The survival function, a complementary concept to the cumulative distribution function (cdf), is the probability that duration equals or exceeds, which is defined by:

$$
\begin{aligned}
& S(t)=\operatorname{Pr}[T>t] \\
& \quad=1-F(t)
\end{aligned}
$$

where $T$ denotes duration in a state and is a nonnegative random variable.

Another key concept is the hazard function, which is the instantaneous probability of leaving a state conditional on survival to time $t$. This is defined as:

$$
\begin{aligned}
& \lambda(t)=\lim _{\Delta t \rightarrow 0} \frac{\operatorname{Pr}[t \leq T<t+\Delta t \mid T \geq t]}{\Delta t} \\
& =\frac{f(t)}{S(t)}
\end{aligned}
$$

(Cameron and Trivedi, 2005).

In regression analysis of transitions the conditional hazard rate, $\lambda(\mathrm{t} \mid \mathrm{x})$, is of fundamental interest. Through the conditional hazard rate is possible to investigate what factors affect the risk of occurrence of the event. Therefore, hazard function is conditioned by the vector of observable 
explanatory variables, because it is considered that the condition in the labour market is affected by a vector of variables that represent the characteristics of individuals, such as level of education, race, region of residence, sex, among others.

In regression analysis of transitions, it is necessary to specify a probability distribution for the failure time on the hazard function. The probability distributions that are used in this type of analysis are exponential, Weibull, log-normal, log-logistic, Gompertz, and the generalized gamma.

Moreover, since workers may be clustered by unobserved heterogeneity (motivation, ability, among others), the estimated parameters may be inefficient, if not, consider unobserved heterogeneity (Heckman and Singer, 1984). A survival model with unobservable heterogeneity is called frailty model. At the observation level, frailty is introduced as an unobservable multiplicative effect, $\xi$, on the hazard function, such that

$$
\lambda(t \mid \xi)=\xi \lambda(\mathrm{t})
$$

where $\lambda(t)$ is a non-frailty hazard function, say, the hazard function of any of the six parametric models supported by a survival analysis. The frailty, $\xi$, is a random positive quantity and is assumed to have mean 1 and variance $\theta$. A way to control the effect of unobserved variables is the use of survival model with Gamma or Inverse-Gaussian correction.

Finally, in this analysis, we have also considered censoring. Censoring means that the events occurred at some time when the subject was not under observation.

In the left censoring, the failure event occurs prior to the subject entering in the study. For example, an individual who is employed in formal sector when interviewed is considered left censored, because the transition from informality to formality happened prior to the beginning of the follow-up period.

In right censoring, the study is run for a specified length of time and by the end of that time, some individuals have not yet experimented the failure event.

Given the presence of both types of censoring, the present paper develops an analysis taking into account censoring.

\subsection{Non-parametric methodology}

It is often useful to know the shape of the unconditional hazard or survival function before considering the analysis with regressors. 
Non-parametric methodology allows a quick diagnosis of the form of the survival function and comparisons between groups, which may assist in further specification of a parametric model.

In non-parametric methods, parameters are not estimated, indeed descriptive analysis of the data are used, such as tables of survival. The advantage of using the non-parametric methods is the lack of restrictions on the model and they do not require the choice of a specific probability distribution. Moreover, there are some negative aspects of this methodology. Since they do not provide estimates of coefficients, there is no way to quantify the effect of covariates on survival time or the transition. Furthermore, there is no way to control the effect of a covariate by another and the conclusions may be incomplete or even misleading. However, the method can be useful for screening a large number of covariates prior to estimation of the regression models (Tomás, 2007).

According to Cameron and Trivedi (2005), considering the concept of the survival function, Kaplan-Meier estimator can be defined as follows:

$$
\hat{S}(t)=\prod_{j \mid t_{j} \leq t}\left(1-\hat{\lambda}_{j}\right)=\prod_{j \mid t_{j} \leq t} \frac{r_{j}-d_{j}}{r_{j}}
$$

where $\lambda_{j}=d_{j} / r_{j}$ is hazard function, $d_{j}$ is the number of spells ending at time $t_{j}$ and $r_{j}$ is the risk of failure at time $t_{j}$ that is before time $t_{j}$.

\subsection{Database}

The database used in this study comes from the micro-data from the Monthly Employment Survey (PME) collected by Brazilian Institute of Geography and Statistics (IBGE) for the period January 2004 to December 2013.

PME is obtained from a probability sample of approximately 40,000 households located in the Metropolitan Regions of Rio de Janeiro, São Paulo, Porto Alegre, Belo Horizonte, Recife, and Salvador. The basic objective of the survey is employment, adding some demographic and educational characteristics with the objective of enabling better understanding of this topic (Perez-Ribas and Dillon-Soares, 2008).

PME is a monthly household survey and follows a different methodology from other Brazilian household surveys. There is a scheme of rotation groups and panels where each sample household is interviewed for four consecutive months, then, it is excluded from the sample for eight consecutive months and reinserted for another period of four consecutive interviews, when it is finally excluded from the sample. The structure of 
the research makes possible to follow the same individual over a period of four consecutive months in the first and second interview (Dos-SantosQueiroz et al., 2012).

An interesting aspect of PME is the fact that it makes possible the study of transitions, given the characteristic of being a panel data that follows each household during eight surveys. However, we have to underline the aspect that PME surveys household and not individuals, and, for this, it can happen that some individuals cannot be followed for eight months. That is, individuals change household during their life and so exit from the survey before the time or enter when it has already started. Thus, it can be affirmed that PME is an unbalanced or incomplete panel from the individual's point of view ${ }^{1}$.

The PME does not report a code that allows identifying with certainty the same person at different times. To circumvent this problem, it is common to use some individual characteristics reported in the survey to identify the same person in two or more interviews. For doing it, this paper uses a pairing algorithm that is provided in Perez-Ribas and DillonSoares (2008).

Moreover, it is important to highlight that the sample used in this article consists of individuals over the age of 16 .

Regarding the characteristics of the workers, the following attributes for analysis of the transition from informality to formality were selected: sex, ethnicity, household head, age, schooling, metropolitan area, and economic sector.

Table A1 in appendix gives a description of the selected variables. Table 2, below, shows descriptive statistics of the sample of workers that passed from informality to formality.

According to this data, it can be noted that workers that passed from informality to formality during the time considered are on average more from male sex than from female sex. It is also important to note that the general data of the population considered in the survey indicate that women are more than men on average.

Means about ethnicity and being household head indicate that these characteristics seem to have a slight effect on transition from informality to formality. White individuals that experimented transition are slightly more on average than non-white individuals, while in the general data the two groups are equal on average. People that are household head

1 The PME was discontinued in February 2016 and replaced by the Continuous PNAD, a quarterly survey started in the first quarter of 2012. The two surveys coexisted between 2012 and 2016. The Continuous PNAD, overcoming the evidenced problems of PME, cannot be considered an unbalanced or incomplete panel. 
Table 2

\section{Descriptive statistics}

\begin{tabular}{lcccc}
\hline \multirow{1}{*}{ Variable } & \multicolumn{2}{c}{ Transition } & \multicolumn{2}{c}{ General } \\
\cline { 2 - 5 } Sex & Mean & Std. Dev. & Mean & Std. Dev. \\
Male & & & & \\
Female & 0.571 & 0.495 & 0.470 & 0.499 \\
Ethnicity & 0.429 & 0.495 & 0.530 & 0.499 \\
White & & & & \\
Non-white & 0.514 & 0.500 & 0.499 & 0.499 \\
Household head & 0.486 & 0.500 & 0.501 & 0.499 \\
Yes & & & & \\
No & 0.436 & 0.496 & 0.325 & 0.468 \\
Age group & 0.564 & 0.496 & 0.675 & 0.468 \\
16-25 & & & & \\
26-35 & 0.225 & 0.418 & 0.222 & 0.377 \\
36-45 & 0.324 & 0.468 & 0.211 & 0.370 \\
$>$ 46 & 0.247 & 0.431 & 0.192 & 0.356 \\
Schooling & 0.202 & 0.402 & 0.374 & 0.453 \\
<1 & & & & \\
1 - 3 & 0.012 & 0.109 & 0.043 & 0.184 \\
4 -7 & 0.032 & 0.175 & 0.064 & 0.252 \\
8 - 10 & 0.174 & 0.379 & 0.240 & 0.433 \\
$>$ 11 & 0.180 & 0.384 & 0.194 & 0.368 \\
Metropolitan area & 0.600 & 0.490 & 0.455 & 0.478 \\
Recife & & & & \\
Salvador & 0.104 & 0.305 & 0.136 & 0.344 \\
Belo Horizonte & 0.110 & 0.312 & 0.121 & 0.326 \\
Rio de Janeiro & 0.213 & 0.410 & 0.195 & 0.396 \\
Sáo Paulo & 0.165 & 0.371 & 0.180 & 0.384 \\
Porto Alegre & 0.242 & 0.429 & 0.216 & 0.412 \\
Economic sector & 0.166 & 0.372 & 0.152 & 0.359 \\
Industry & & & & \\
Services & 0.215 & 0.408 & 0.160 & 0.258 \\
\hline Sorres & 0.785 & 0.410 & 0.840 & 0.484 \\
\hline
\end{tabular}

Source: own elaboration, pesquisa mensal de emprego (IBGE, 2004-2013).

transit less than others according to the data of transition group, but this fact may be due to a lower presence of individuals with this characteristic in the overall data.

According to age groups, individuals who transited more are those with an age comprised between 26 and 35 years, followed by those between 36 and 45 . However, the most interesting data is about workers with 46 or more years, which have the lowest mean in the case of transition, while it is the more present group in the database according to the overall data.

Considering the level of schooling, it appears that having studied 11 years or more has a large effect on the transition from informality to formality. The two prior education groups (4-7 years and 8-10 years) have 
some effect, but not comparable with the last group. Moreover, the group of workers that studied 11 years or more has a larger mean in the case of transition than in the overall data.

The analysis of descriptive statistics continues considering metropolitan areas: São Paulo and Belo Horizonte are the metropolitan areas where on average more individuals transited from informal to formal jobs, but are also the cities with more individuals in the database; on the other side, Recife appears to be the city where this happened less.

Finally, the sector of services is on average the economic sector where transition occurred more on average during the time analysed. Also in this case, we have to remember that services is the sector with more presence in the general data.

\section{Empirical results}

Empirical results are presented using two categories of models: parametric and non-parametric. The goal is to complement the two models to increase, in this way, the power of explanation.

The time between January 2004 and December 2013 is expressed in (120) months.

\subsection{Non-parametric models}

Figure 4, below, presents the estimation of the survival function of workers by sex. The data show that men have a lower probability than women to continue in informal sector for all months, especially after the beginning month and before the ending months.

After 79 months, men have $75 \%$ of chances to remain informal, while women reach this level only after 95 months.

The biggest difference of probability between women and men is observed in the $117^{\text {th }}$ month, where men have a probability to continue in informality of $31.20 \%$ while women of $45.26 \%$, a difference of 14.06 percentage points. In the last month, men have a probability to remain in the informal sector of $31.30 \%$, while women of $18.25 \%$, a difference of 13.05 percentage points.

The successive analysis is about survival estimates by years of schooling, showed in figure 5 below.

It is evident that passing from a group of fewer years of study to a group of more years leads to a reduction in the probability of a worker remaining in informal sector. The top curve describes the probability of individuals with less than one year of schooling, the curves below correspond to gradually more years of study, until the bottom curve that 


\section{Figure 4}

\section{Kaplan-meier survival estimates by sex}

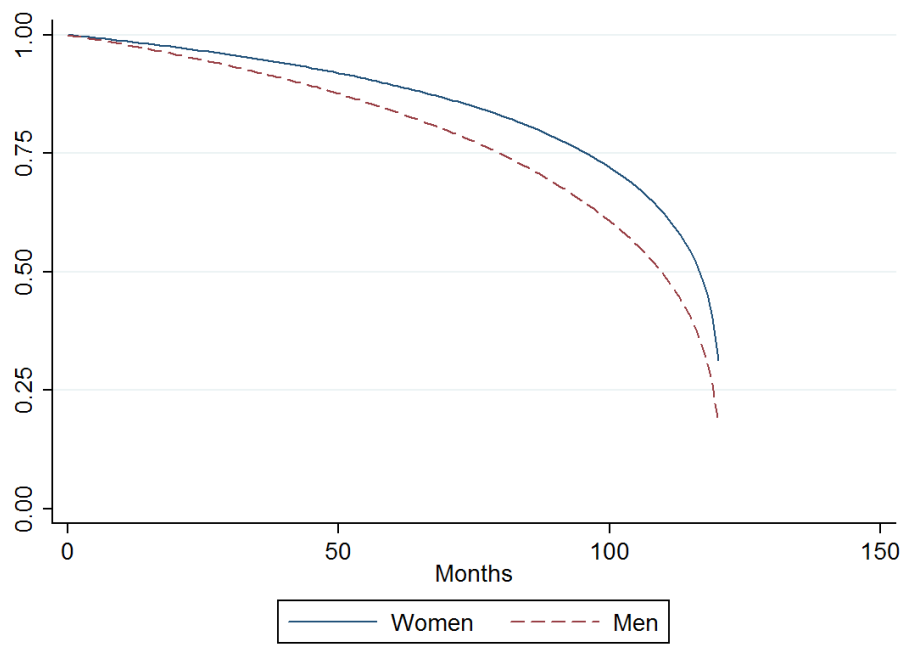

Source: own elaboration, pesquisa mensal de emprego (IBGE, 2004-2013).

\section{Figure 5}

Kaplan-meier survival estimates by years of schooling

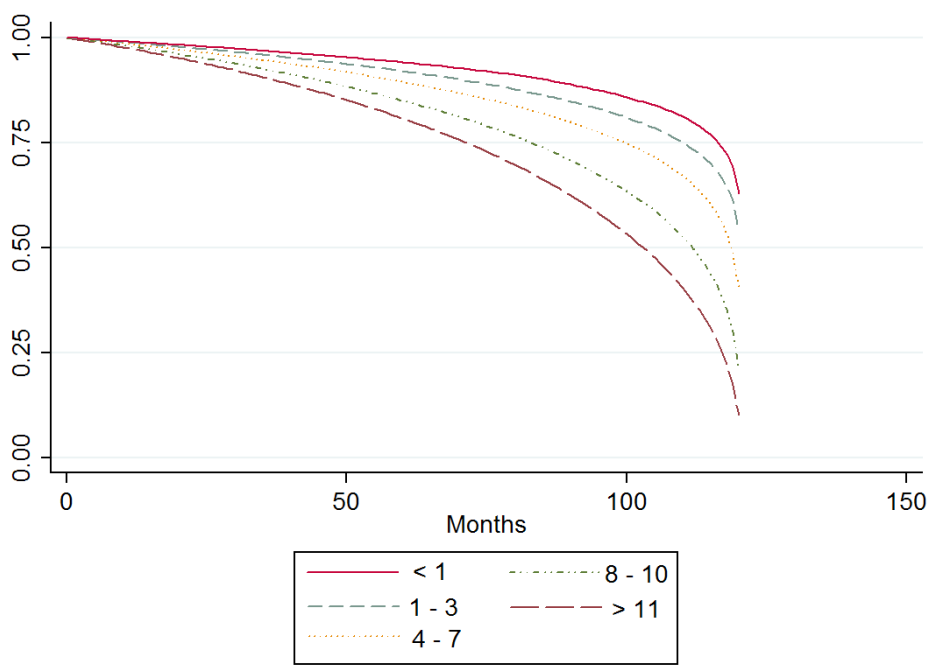

Source: own elaboration, pesquisa mensal de emprego (IBGE, 2004-2013). 
defines more than 11 years of education. In fact, workers with more than 11 years of schooling decrease the probability of remaining in informality by $25 \%$ after 70 months, while workers with $8-10$ years after 82 months, workers with 4-7 years after 98 months, workers with 1-3 years after 109 months and workers with less than 1 year after 115 months.

Continuing in the same analysis, considering the reduction of chance by $50 \%$ we can observe that only workers with more than 3 years of schooling reach this level before the $120^{\text {th }}$ month.

The next graph (figure 6) shows the probability of surviving in informal sector by age. The most relevant aspect is the difference in the curves between the group of workers with age more than 45 ('>46') and the other groups of age. On the other hand, individuals more likely to exit informality are those belonging to 26-35 group and 36-45 group.

For example, the group ' $>46$ ' reaches probability of $75 \%$ only after 102 months, while the other groups achieve this level between the $60^{\text {th }}$ and $74^{\text {th }}$ month; moreover, this group of older workers achieves $50 \%$ of probability only at the penultimate month, whilst the other groups arrive at this point well before.

\section{Figure 6 \\ Kaplan-meier survival estimates by age}

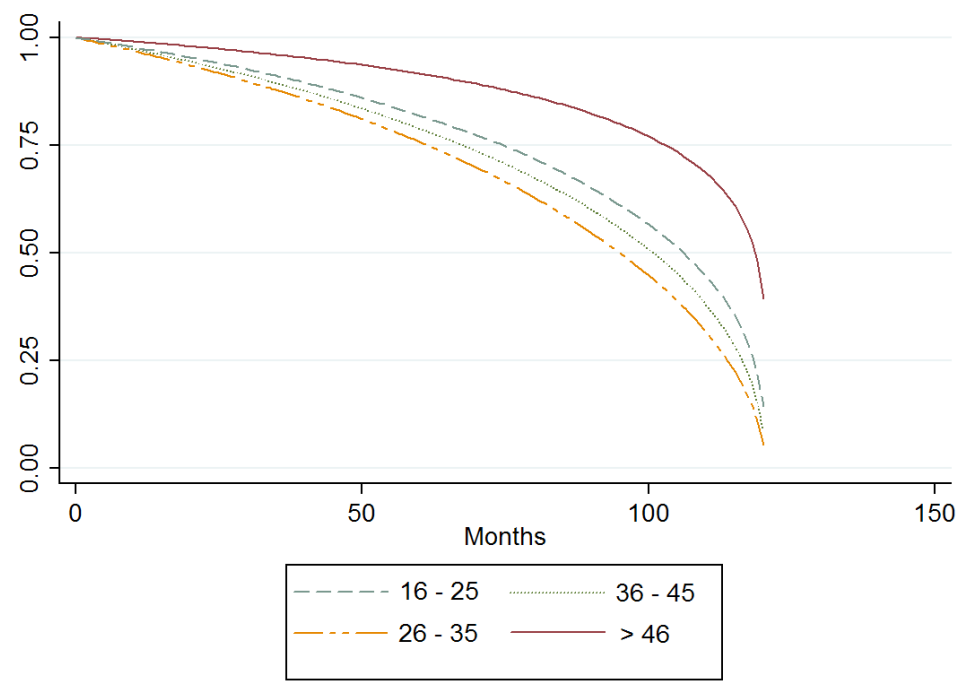

Source: own elaboration, pesquisa mensal de emprego (IBGE, 2004-2013).

Figure 7, below, provides an analysis of survival probability by ethnicity. It can be easily perceived that there is no relevant difference between white and non-white workers; the curves follow almost the same path. 
According to this figure, it appears that ethnicity is an individual characteristic that has a small role in explaining the transition from informal to formal labour.

\section{Figure 7}

Kaplan-meier survival estimates by ethnicity

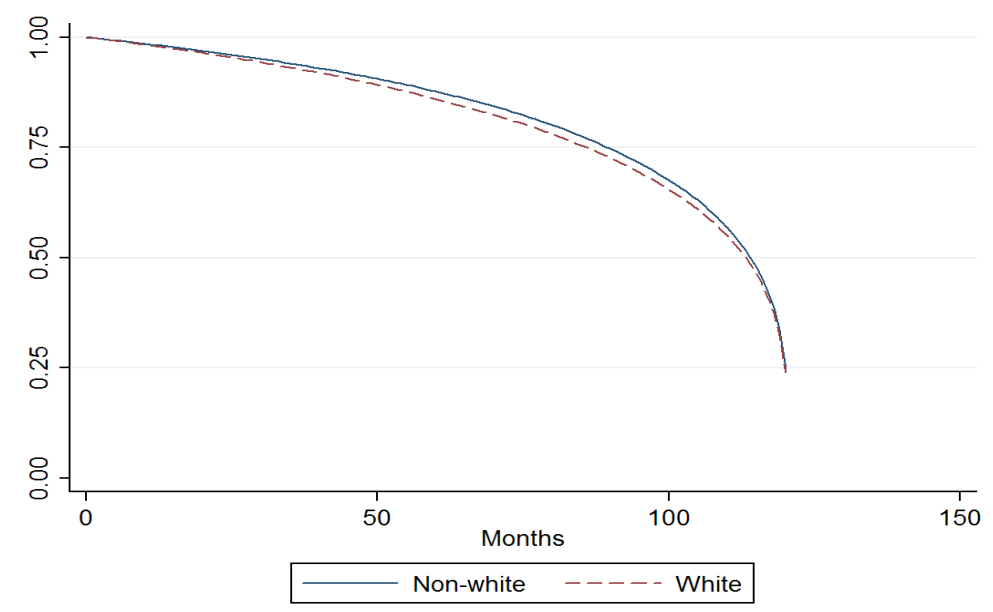

Source: own elaboration, pesquisa mensal de emprego (IBGE, 2004-2013).

Figure 8 makes available Kaplan-Meier survival estimates by the condition of being or not being head of the household. It seems that being head of household can be considered a characteristic that explains the transition from informal to formal labour. For instance, an individual that is head of household reaches probability of $75 \%$ after 77 months, while other individuals come to this level after 94 months. A similar delay happens when we observe the probability of $50 \%$ : head of household reaches this level after 108 months, while other people after 116 months.

In the figure 9, we can observe survival estimates by metropolitan cities. The metropolitan region of Recife appears to be the worst in comparison to the other metropolitan cities. In fact, the curve of Recife has a different path: considering the chance to remain informal of $75 \%$, we can observe that a worker that lives in Recife reaches this level in the $97^{\text {th }}$ month, while workers living in other metropolitan cities come to this probability between the $83^{\text {rd }}$ and $91^{\text {st }}$ month. 


\section{Figure 8}

\section{Kaplan-meier survival estimates by condition in the household}

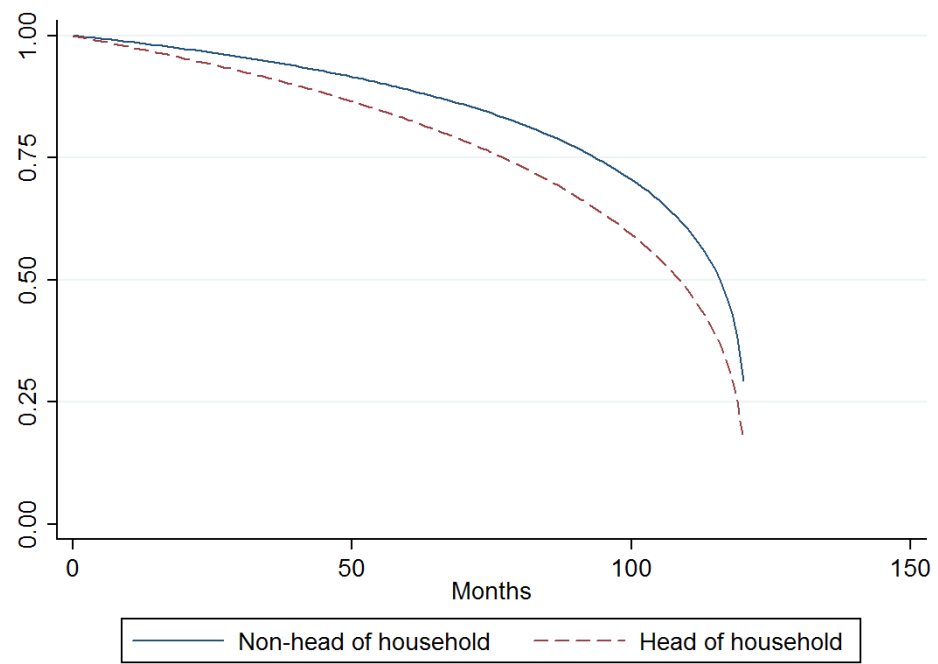

Source: own elaboration, pesquisa mensal de emprego (IBGE, 2004-2013).

\section{Figure 9}

\section{Kaplan-meier survival estimates by metropolitan cities}

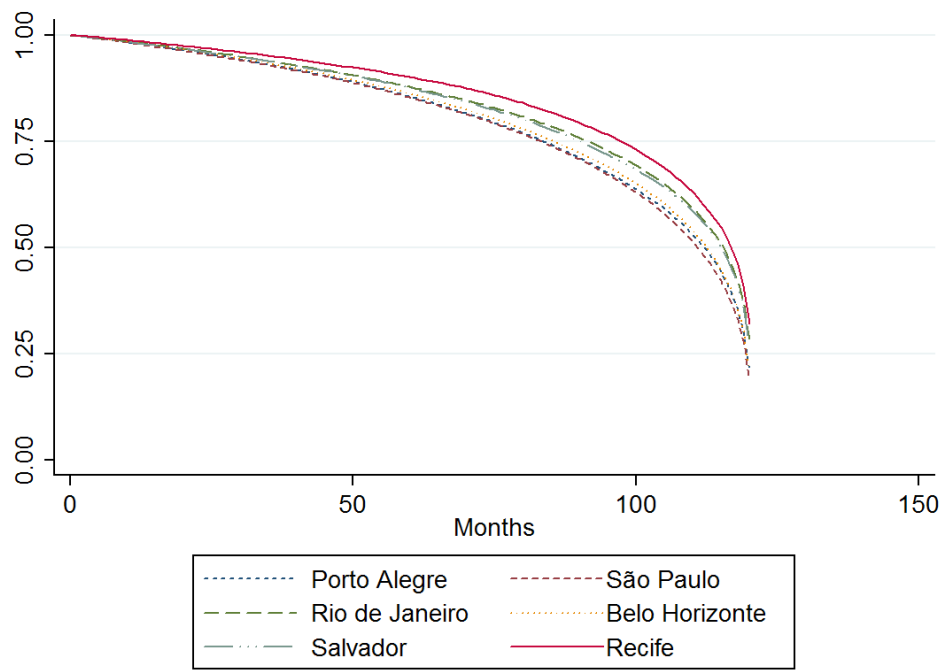

Source: own elaboration, pesquisa mensal de emprego (IBGE, 2004-2013).

Finally, the last graph (figure 10) is about survival estimates by sector of activity. 
Figure 10

Kaplan-meier survival estimates by sector of activity

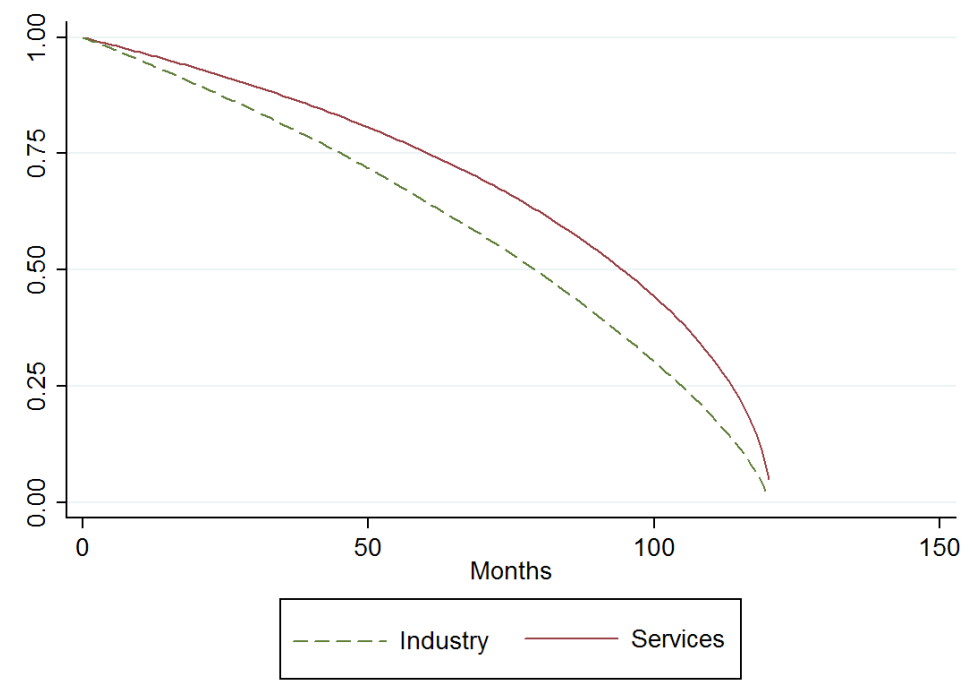

Source: own elaboration, pesquisa mensal de emprego (IBGE, 2004-2013).

We can note that workers employed in the sector of services have the lowest probability to exit informality, while individuals employed in industry have the largest. Thus, it appears that the variables linked to the sector of activity have a role in increasing the chances of transition from informality to formality. The largest difference in the chances to remain informal can be noted in the centre of the graph, between the $50^{\text {th }}$ and the $100^{\text {th }}$ month.

\subsection{Parametric models}

In this section results obtained through parametric models of duration are presented and commented.

The regression is developed controlling the level of unemployment in each month in each metropolitan city and taking into account left and right censoring.

When we use parametric models, we should choose the probability distribution that fits best the variable of formality, given that the results may be biased if the distribution is not correct. To choose the best distribution that describes the variable of formality, the following methods can be used: a graphic method and AIC scores.

In the first method, to test the adequacy of the Weibull distribution and the exponential model, we build a graph with the value of in $y$-axis 
and the value of in $\mathrm{x}$-axis, where is the survival function obtained by the Kaplan-Meier method. According to Colosimo (2001), the Weibull distribution is most suitable if the graph obtained is approximately linear. If, in addition to linearity, the graph passes through the origin and has a slope equal to one, the best fit is given by the exponential distribution.

\section{Figure 11 \\ Adequacy test}

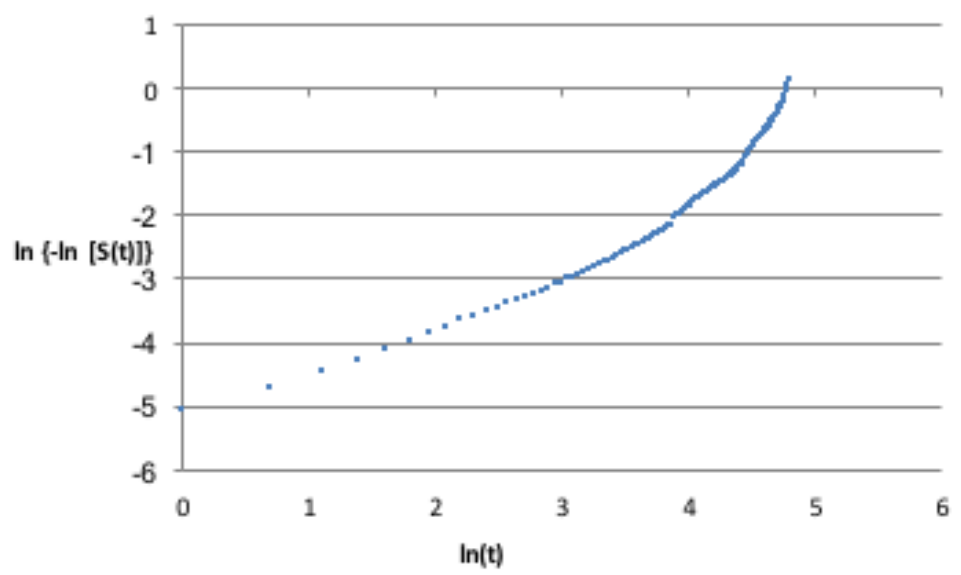

Source: own elaboration, pesquisa mensal de emprego (IBGE, 2004-2013).

The graph (figure 11) is prevalently linear, presenting no significant deviation. However, the other two conditions are not met, namely: passing through the origin and having a slope equal to one. Thus, according to the graphic method, it seems that the best distribution to be used in this case is Weibull.

Seeking to verify the accuracy of the graphical analysis, we also use the second method, that is, comparing AIC scores.

Akaike's Information Criterion (AIC) is used to distinguish between different parametric models. Typically, models whose log-likelihood is small are preferred. Akaike's method penalizes each model's log likelihood to reflect the number of parameters that are being estimated and then compares them:

$$
A I C=-2 \ln L+2(k+c)
$$

where $k$ is the number of model covariates and $c$ is the number of model specific distributional parameters. Essentially, the method consists of a comparison between the AIC scores for different parametric models and the selection of the biggest one with the smallest AIC score (Jenkins, 2008). 
The following table 3 shows AIC scores for different parametric distribution according to the model of this paper.

\section{Table 3}

Aic scores

\begin{tabular}{lc}
\hline \multicolumn{1}{c}{ Model } & AIC \\
\hline Exponential & $1,987,823$ \\
Weibull & $1,563,169$ \\
Gompertz & $1,783,905$ \\
Log-normal & $1,902,837$ \\
Log-logistic & $1,820,558$ \\
Gamma & $1,766,411$ \\
\hline
\end{tabular}

Source: own elaboration, pesquisa mensal de emprego (IBGE, 2004-2013).

According to table 3, it can be affirmed that the Weibull distribution is the one which fits best. This result confirms the findings obtained by graphical analysis. Thus, the model with Weibull distribution for the survival time into informality is the one considered in the analysis.

Another issue that has to be addressed is about the presence of unobserved heterogeneity. One can estimate frailty models and test whether unobserved heterogeneity is relevant using likelihood ratio tests based on survival model with Gamma or Inverse-Gaussian correction and model without frailty correction. Both models yield a test statistics on the frailty variance that lead us to accept the null hypothesis that $=0$ in equation of section 3.1. This suggests that unobserved heterogeneity is not affecting our model.

Table 4 presents parametric results in the format of hazard ratios. Each value minus one provides the percentage change of each variable in the probability to transit to formal jobs, in comparison with the category of reference.

It appears that if the individual is a man the probability of transition to formality is largest in comparison to a feminine individual. A male worker has $29.7 \%$ more probability to transit into the formal sector than a female worker.

Workers with an age between 16 and 25, between 26 and 35, and between 36 and 45 have more probability of transition than workers aged more than 46 (table 4). The most relevant result is about the group of workers aged between 26 and 35 with a probability of transition of $201.8 \%$ larger than the group of workers aged more than 46 years. 
Table 4

Parametric results (hazard ratios)

\begin{tabular}{lc}
\hline \multicolumn{1}{c}{ Variables } & Hazard Ratios \\
\hline man & $1.297^{* * *}$ \\
sch $<1$ & Reference \\
sch1_3 & $4.048^{* * *}$ \\
sch4_7 & $5.050^{* * *}$ \\
sch8_10 & $6.362^{* * *}$ \\
sch>11 & $8.760^{* * *}$ \\
age1625 & $2.515^{* * *}$ \\
age2635 & $3.018^{* * *}$ \\
age3645 & $2.635^{* * *}$ \\
agemore46 & Reference \\
white & $0.916^{* * *}$ \\
hhh & $1.332^{* * *}$ \\
recife & Reference \\
sp & $3.283^{* * *}$ \\
salvador & $0.431^{* * *}$ \\
bh & $10.878^{* * *}$ \\
rj & $8.320^{* * *}$ \\
poa & $15.973^{* * *}$ \\
serv & Reference \\
ind & $2.145^{* * *}$ \\
constant & $0.001^{* * *}$ \\
\hline
\end{tabular}

Significance levels: ${ }^{*} 10$ percent, ${ }^{* *} 5$ percent, ${ }^{* * *} 1$ percent

Source: own elaboration, pesquisa mensal de emprego (IBGE, 2004-2013).

However, the largest hazard ratios are those regarding schooling, in particular, for individuals with more than 11 years of education. Moreover, the more the years of schooling, the larger the hazard ratios are. For instance, having 11 years of schooling or more leads to an increase in the probability of transition to formality by $776.0 \%$, in comparison to having less than 1 year.

Continuing with the analysis of the results, it can be noted that the variable white has little relevance to explaining transition to formality; the hazard ration in this case is very close to 1 .

The next characteristic, being head of household, is slightly more relevant: workers with this characteristic have a probability to enter in a formal job increased by $33.2 \%$ than other workers.

Regarding metropolitan areas, all cities, with the exception of Salvador, have a larger probability of transition to formality than Recife (table 4). It appears that the transition to formality is more difficult in Recife and Salvador, metropolitan cities of Northeast of Brazil, while very easy in Belo Horizonte and Porto Alegre, which show huge hazard ratios. The results relative to metropolitan cities are a network of unemployment in 
the region, given that it was controlled by level of unemployment of each metropolitan city.

The last variables provide the evidence that workers in the sector of industry seem to have a higher probability $(114.5 \%)$ of transition to formality than workers in the sector of services.

\section{Conclusions}

Considering all the methods of analysis of this essay, some hypothesis about the transition from informal to formal sector can be made.

The level of education is a characteristic that seems to have a great effect on the transition from informality to formality. In fact, we observe that the probability to transit to formality increases according to the years of education.

Recent literature about this topic confirms these results. BarbosaFilho et al. (2012) affirm that the fall of informality by $6.2 \%$ occurred between 2002 and 2009 is one of the successes of the policy of universalization of education in the country. Thus, from the public policy viewpoint, the more education will be stimulated, the larger the reduction of informality in Brazil will be.

Another group of variables that may have a big role in explaining transitions is that relative to metropolitan cities. Belo Horizonte, Rio de Janeiro, and Porto Alegre are the metropolitan areas where transition has a larger probability to happen than the others areas.

The sector of activity also has an important role in clarifying this type of transition. It appears that industry, being a sector where individuals are easily employed in the formality, has had a larger role in the reduction of informality in the period considered.

Age is a characteristic that appears to be significant in explaining transitions from informality to formality. In particular, we have to mention the importance of the age group between 26 and 35 years, which has the largest hazard ratio.

The variables relating to sex and head of household seem to have a lower effect than previous variables, but cannot be disregarded. In particular, hazard ratios are in agreement with our initial suppositions: men and heads of household have more probability to transit to formality than women and individuals with other positions in the household.

Finally, another important conclusion is that ethnicity appears to have almost no effect in explaining transition to formal job. The lack of effect of this variable may be explained by the fact that, when the level of education is controlled, the difficulties and the disadvantages that black and brown people suffer in the job market may disappear. Thus, in Brazil, the 
lack of opportunities that black and brown people have in the job market may be due mostly to their low levels of schooling, which is a consequence of inequality of opportunities to access educational system.

\section{Appendix}

\section{A1. Description of selected variables}

\begin{tabular}{|c|c|c|}
\hline Variable & Description & Obs \\
\hline forminf & $1=$ formal worker; $0=$ informal worker & Transition var. \\
\hline man & $1=\operatorname{man} ; 0=$ woman & \\
\hline age 1625 & $1=$ age between 16 and 25 (included); $0=$ otherwise & \\
\hline age 2635 & $1=$ age between 26 and 35(included); $0=$ otherwise & \\
\hline age 3645 & $1=$ age between 36 and 45 (included); $0=$ otherwise & \\
\hline agemore 46 & $1=$ age more than 46 (included); $0=$ otherwise & Ref. category \\
\hline $\operatorname{sch}<1$ & $1=$ schooling less than 1 year; $0=$ otherwise & Ref. category \\
\hline sch1_3 & $1=$ schooling between 1 and 3 years(included); $0=$ otherwise & \\
\hline sch4_7 & $1=$ schooling between 4 and 7 years(included); $0=$ otherwise & \\
\hline sch8_10 & $\begin{array}{l}1=\text { schooling between } 8 \text { and } 10 \text { years(included);0= otherwi- } \\
\text { se }\end{array}$ & \\
\hline $\operatorname{sch}>11$ & $1=$ schooling more than 11 years (included); $0=$ otherwise & \\
\hline white & $1=$ white $0=$ non-white & \\
\hline hhh & $1=$ head of household; $0=$ otherwise & \\
\hline recife & $1=$ lives in metropolitan area of Recife; $0=$ otherwise & Ref. category \\
\hline sp & $1=$ lives in metropolitan area of São Paulo; $0=$ otherwise & \\
\hline salvador & $1=$ lives in metropolitan area of Salvador; $0=$ otherwise & \\
\hline bh & $\begin{array}{l}1=\text { lives in metropolitan area of Belo Horizonte; } 0=\text { otherwi- } \\
\text { se }\end{array}$ & \\
\hline rj & $1=$ lives in metropolitan area of Rio de Janeiro; $0=$ otherwise & \\
\hline poa & $1=$ lives in metropolitan area of Porto Alegre; $0=$ otherwise & \\
\hline serv & $1=$ employed in services sector; $0=$ otherwise & Ref. category \\
\hline ind & $1=$ employed in industry sector; $0=$ otherwise & \\
\hline
\end{tabular}

Source: own elaboration, pesquisa mensal de emprego (IBGE 2004-2013).

\section{References}

Barbosa-Filho, Fernando Holanda and Rodrigo Leandro de Moura (2012), "Evolução recente da informalidade no Brasil: uma analise segundo características da oferta e demanda de trabalho", Texto para discussão No.17, Instituto Brasileiro de Economia-Fundação Getúlio Vargas, Rio de Janeiro, Brazil.

Barros, Ricardo Paes, Ricardo Mello and Valéria Pero (1993), "Informal labor contracts: a solution or a problem?", texto para discussão 
num. 291, Instituto de Pesquisa Econômica Aplicada, Brasília. Brazil.

Barros, Ricardo Paes, José Guilherme Reis-Almeida and José Rodriguez (1990), "Segmentação no mercado de trabalho: a carteira de trabalho na construção civil", Revista de Econometria, 10 (2), Sociedade Brasileira de Econometria, Rio de Janeiro, Brazil, pp. 313-35.

Cacciamali, Maria Cristina and Reynaldo Fernandes (1993), "Distribuição dos trabalhadores e diferenciais de salários entre mercados de trabalho regulamentado e náo regulamentado", Pesquisa e Planejamento Econômico, 23 (1), Instituto de Pesquisa Econômica Aplicada, Rio de Janeiro, Brazil, pp.135-156.

Cacciamali, Maria Cristina and Maria Fatima José-Silva (2003), "Emprego e seguridade social: mais uma década perdida no mercado de trabalho da América Latina", in O. Coggiola, América Latina. Encruzilhadas da História Contemporânea, Xamã, São Paulo, Brazil, pp. 215-232.

Cameron, Colin and Pravin Trivedi (2005), Microeconometrics: Methods and Applications. Cambridge University Press, Cambridge, England.

Carneiro, Francisco Galrão and Andrew Henley (2001), "Modelling Formal vs. Informal Employment and Earnings: microeconomic evidence for Brazil", XXIX annual meeting of Anpec, Brazilian Association of Graduate Programs in Economics, 11-14 December, Salvador de Bahia, Brazil.

Colosimo, Enrico Antonio (2001), "Analise de sobrevivência aplicada", Paper presented at Reunião Anual da Região Brasileira da Sociedade Internacional de Biometria, No. 46, 7-13 July, Piracicaba, Brazil.

Curi, Andréa and Naércio Aquino Menezes-Filho (2004), "Os determinantes das transiçóes ocupacionais no mercado de trabalho Brasileiro", Prooceding of the XXXII annual meeting of Anpec, Brazilian Association of Graduate Programs in Economics, 7-10 December, Joao Pessoa, Brazil. 
Dos Santos-Queiroz, Vivian, Hilton Martins de Brito-Ramalho and Paulo Aguiar, do Monte (2012), "A inserção do idoso no mercado de trabalho: evidencias a partir da duração do desemprego no Brasil”, paper presented at Forum BNB de Desenvolvimento, XVII Encontro Regional de Economia, 19-20 July, Fortaleza, Brazil.

Gonzalez de la Rocha, Mercedes (1994), The resources of poverty: women and survival in a Mexican city, Blackwell, Oxford, United Kingdom.

Heckman, James and Burton Singer (1984), "The Identifiability of the Proportional Hazard Model”, The Review of Economic Studies, 51 (2), The Review of Economic Studies Ltd, Stockholm, Sweden, pp. 231-243.

IBGE (Instituto Brasileiro de Geografia e Estatística) (1992-2012). "Pesquisa nacional por amostra de domicílios: PNAD”, IBGE, Rio de Janeiro, Brazil.

IBGE (Instituto Brasileiro de Geografia e Estatística) (2004-2013). "Pesquisa mensal de emprego: PME”, IBGE, Rio de Janeiro, Brazil.

IPEA (Instituto de Pesquisa Economica Aplicada) (2011), "Características da formalização do mercado de trabalho brasileiro entre 2001 e 2009”, Comunicados da Ipea, No. 88, IPEA, Brasília, Brazil.

ILO (International Labour Organization) (2014), "Transitioning from the informal to the formal economy", paper presented at International Labour Conference, 103rd Session, Geneva, 28 May-12 June, International Labour Office, Geneva, Switzerland.

Jenkins, Stephen (2008), Survival Analysis, unpublished manuscript, Institute for Social and Economic Research, University of Essex, Colchester, England.

Lancaster, Tony (1979), "Econometric methods for the duration of unemployment", Econometrica 47 (4), Econometric Society, New York, United States of America, pp. 939-56.

Maloney, William Francis (1999), "Does informality imply segmentation in urban labour markets? Evidence from sectoral transitions in 
Mexico", World Bank Economic Review, 13 (2), Oxford University Press, Oxford, United Kingdom, pp. 275-302.

Neri, Marcelo Cortês, (2002), "Decent work and the informal sector in Brazil", Ensaios Econômicos, working paper No. 461, Escola Brasileira de Economia e Finanças-Fundação Getulio Vargas, Rio de Janeiro, Brazil.

Perez-Ribas, Rafael and Sergei Dillon-Soares (2008), "Sobre o painel da Pesquisa Mensal de Emprego (PME) do IBGE”, Texto para discussão - Ipea, No. 1348, Instituto de Pesquisa Econômica Aplicada, Rio de Janeiro, Brazil.

Tomás, Maria Carolina (2007), "O ingresso dos jovens no mercado de trabalho: uma análise das regiōes metropolitanas brasileiras nas últimas décadas", master dissertation, Cedeplar, Universidade Federal de Minas Gerais, Belo Horizonte, Brazil.

Valdivia-López, Marcos and Mercedes Pedrero-Nieto (2011), "Segmentación laboral, educación y desigualdad salarial en México", Revista Mexicana de Sociología, 73 (1), Instituto de Investigaciones Sociales-Universidad Nacional Autónoma de México, Ciudad de México, pp. 139-175.

Recibido: 1 de octubre 2015. Corregido: 20 de diciembre de 2016. Aceptado: 10 de febrero de 2017.

Michele Romanello. Italian. He received his Ph.D. in Development Economics from Federal University of Paraná in 2014. Currently, he is Adjunct Professor in the Department of Economics and International Relations at Federal University of Santa Catarina (Brazil). Previously, he was a researcher at International Policy Centre for Inclusive Growth, research centre of United National Development Programme. His research has been focused on education, inequality, and development economics. His recent publication is: "Formality or informality: a choice based on individual characteristics", Revista Espacios, 35 (6), Asociación de Profesionales y Técnicos del CONICIT, Caracas, Venezuela, p. 4 (2014); "The private and social return to education considering the characteristics of society", Revista Espacios, 38 (15), Asociación de Profesionales y Técnicos del CONICIT, Caracas, Venezuela, p. 13 (2017). 
Flávio de Oliveira Gonçalves. Brazilian. He received his Ph.D. from University of Brasília (Brazil) in 2002. Currently, he is adjunct professor at the Federal University of Paraná (Brazil). His research has been focused on education, inequality, growth and innovation. His recent publications are: in co-authorship, "Eficiência na provisão de educação pública municipal: uma análise em três estágios dos municípios brasileiros”, Estudos Econômicos, 43 (2), FEA-USP, São Paulo, Brazil, pp. 271-299, (2013); "Em busca de uma nova taxonomia de regimes tecnológicos para a indústria de transformação brasileira”, Economia, 14 (1), ANPEC, Brasília, Brazil pp. 123-145, (2013); "Igualdade de oportunidade no Brasil entre 1999 e 2009: estimação e decomposição através do valor de Shapley”, Pesquisa e Planejamento Econômico, 42 (2), IPEA, Rio de Janeiro, Brazil, pp. 185-210 (2012). 